\title{
Synthesis of 5-methoxy-I, 2, 3, 4- tetrahydro -2-naphthoic acid
}

\begin{abstract}
A four-step synthesis of 5-methoxy-1, 2, 3, 4-tetrahydro-2-naphthoic acid 5 from 5-methoxy-2-tetralone 1 has been developed. The acid 5 has been considered to be a potential intermediate for optically active 11-deoxyanthracycline antibiotics.
\end{abstract}

Keywords: 2-naphthoic acid, 5-methoxy- $\beta$-tetralone, trimethylsilylcyanide, catalytic hydrogenation
Volume I Issue 5 - 2017

\author{
Kimberly Chinea, Dioni A Arrieche, Ajoy K \\ Banerjee \\ Venezuelan Institute of Scientific Research (IVIC), Venezuela
}

Correspondence: Ajoy K Banerjee, Centro de Química, Venezuelan Institute of Scientific Research, Apartado-21827, Caracas-1020A, Venezuela, Tel +5802125041324 , Fax +5802125041350, Email aabanerje@gmail.com

\section{Introduction}

The route developed ${ }^{1}$ for the title acid 5 from 2-naphthoic acid in five steps (bromination, esterification, methoxylation, alkaline hydrolysis, Birch reduction followed by acid hydrolysis) afforded with an overall yield of $33 \%$. Johnson \& Mander $^{2}$ have also reported the same acid from 5-methoxy-1-tetralone in three steps (carboxylation, hydrogenolysis, alkaline hydrolysis) in high overall yield. In this procedure the first two steps were not purified and thus it is very difficult to say the exact overall yield of the pure acid. Moreover the hydrogenolysis experiment was achieved by overnight hydrogenation at high pressure. The process is not recommendable because if the flow of hydrogen is not controlled, it may cause explosion.

The acid 5 was converted by the same authors ${ }^{1}$ to amine as hydrogen chloride salt 6 . The $\alpha$-agonist, $\alpha$-the androgenic, antifungal and dopamine-like activity of the aminotetralin and its $\mathrm{N}$-alkyl substituents are well documented..$^{3-7}$ The interesting biological activities of aminotetralin prompted us to develop an easy route to obtain the acid 5. The details of our efforts are described in present article (Scheme 1).
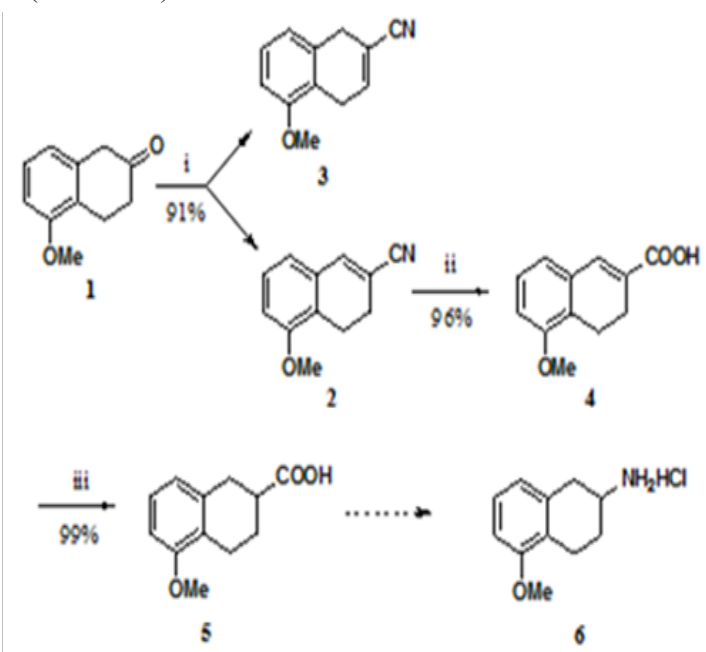

Scheme I: Reagents and conditions: (i) TMSCN, $\mathrm{C}_{6} \mathrm{H}_{6}, \mathrm{Znl}_{2}, \mathrm{rt}, \mathrm{I} 2 \mathrm{~h}$; $\mathrm{Py}, \mathrm{POCL}_{3}$; (ii) $\mathrm{NaOH}-\mathrm{H}_{2} \mathrm{O}$ (50\%); (iii) $\mathrm{H}_{2}, \mathrm{Pd}-\mathrm{C}(\mathrm{I0 \%})$, EtOH.

\section{Results and discussion}

Tetralone 1 on treatment with trimethylsilyl cyanide ${ }^{8}$ in benzene in presence of zinc iodide as catalyst yielded the $\alpha, \beta$-unsaturated nitrile 2 in $91 \%$ yield which is superior compared to the yield (67\%) reported. ${ }^{9}$ The absence of the nitrile 3 was clearly indicated in its ${ }^{1} \mathrm{H}$ NMR spectrum. Heating the nitrile 2 under reflux in microwave oven for 2 hours with an aqueous solution of potassium hydroxide $(50 \% \mathrm{KOH}$ in water) yielded the acid 4 in 96\% yield (overall yield $87 \%$ ) whose alternative synthesis ${ }^{10}$ from 5-methoxy-1-tetralone in four steps (carboxylation, metal hydride reduction, dehydration and alkaline hydrolysis) was reported in an overall yield of $44 \%$. The acid 4 has been considered to be a potential intermediate for optically active 11-deoxyanthracycline antibiotics. ${ }^{10}$ The catalytic hydrogenation over $\mathrm{Pd} / \mathrm{C}(10 \%)$ in absolute ethanol yielded the acid 5 in $99 \%$ yield whose spectroscopic data confirmed the structure assigned. The overall yield of the acid 5 was $87 \%$ which is higher than that published ${ }^{1}$ yield $(33 \%)$.

\section{Experimental}

Unless otherwise stated all melting points are uncorrected and were determined on an Electrothermal melting point apparatus. Infrared (IR) spectra were recorded on a Nicolet-Fourier Transform (FT) instrument and NMR $\left({ }^{1} \mathrm{H}\right.$ and $\left.{ }^{13} \mathrm{C}\right)$ spectra were determined on a Bruker AM-300 spectrometer in $\mathrm{CDCl}_{3}$. Chemical shifts $(\delta)$ are expressed in ppm and multiplicity is defined as s (singlet), d (doublet), $\mathrm{t}$ (triplet) or $\mathrm{m}$ (multiplet) . Mass spectra (MS) were determined on a Dupont 21-492B. Column chromatography was carried out on silica gel 60 (Merck). Thin layer chromatography (TLC) plates were coated with silica gel and the spots were visualized using ultraviolet light. All organic solvents were dried over anhydrous $\mathrm{MgSO}_{4}$ and solvents were evaporated in vacuo. Microwave irradiations were carried out using a CEM Discovery Labmate microwave oven (2.45GHZ, 300W), using flask (100mL) made of Pyrex glass (No 4320), size 24/40mm. Oberon chemically resistant safety goggles (Aldrich Chemical Company) were utilized for carrying out experiments with microwave irradiations and reactions with trimethylsilyl cyanide were carried out in wellventilated hood using appropriate aprons and hand gloves. Elemental analyses were performed on a Carlo-Erba 1108 Elemental Analyser. 


\section{5-Methoxy-2-cyano-3, 4-dihydronaphthalrne (2)}

To a solution of the tetralone $1(0.51 \mathrm{~g}, 2.84 \mathrm{mmol})$ in dry benzene $(20 \mathrm{~mL})$ was added zinc iodide $(40 \mathrm{mg}, 0.12 \mathrm{mmol})$ and trimethylsilyl cyanide $(0.5 \mathrm{~mL}, 4.3 \mathrm{mmol})$ and stirred at room temperature for 12 hours under nitrogen atmosphere. The progress of the reaction was monitored by TLC. To the resulting solution was added pyridine $(3 \mathrm{~mL})$ and phosphorous oxychloride $(0.8 \mathrm{~mL}, 8.5 \mathrm{mmol})$ and the mixture was heated under reflux for 8 hours. The dark solution was cooled, poured into cold hydrochloric acid (10\%) and extracted with ether $(3 \times 10 \mathrm{~mL})$. The organic extracts were washed with brine, dried, evaporated and chromatographed (hexane: ethyl acetate; $6: 4$ ) to obtain the nitrile 2 (481mg, $91 \%$ ), as a colorless solid; $R_{\mathrm{f}} 0.27$ (hexane: ether 7:3), m.p. $42-43^{\circ} \mathrm{C}$ (from hexane) (lit. ${ }^{9} 43-44^{\circ} \mathrm{C}$ ); IR $\left(\mathrm{cm}^{-1}\right): 2214$ (CN); MS (m/z):185 (M+), $170\left(\mathrm{M}^{+}-\mathrm{Me}\right)$ and $154\left(\mathrm{M}^{+}-\mathrm{OMe}\right) ;{ }^{1} \mathrm{H} \mathrm{NMR}$ $(300 \mathrm{MHz}) \delta_{(\mathrm{ppm})}: 7.15-7.17(\mathrm{t}, 1 \mathrm{H}, \mathrm{J}=8.25 \mathrm{~Hz}), 7.12-7.13(\mathrm{t}, 1 \mathrm{H}, \mathrm{ArH}-7$, $\mathrm{J}=1.62 \mathrm{~Hz}), 6.86-6.88(\mathrm{~d}, 1 \mathrm{H}, \mathrm{J}=7.51 \mathrm{~Hz}), 6.75-6.67(\mathrm{~d}, 1 \mathrm{H}, \mathrm{J}=7.51 \mathrm{~Hz})$, $3.82(\mathrm{~s}, 3 \mathrm{H}, \mathrm{OMe}), 2.84-2.87(\mathrm{t}, 2 \mathrm{H}, \mathrm{J}=8.81 \mathrm{~Hz}), 2.45-2.52(\mathrm{t}, 2 \mathrm{H}, \mathrm{J}=$ $8.81 \mathrm{~Hz}) ;{ }^{13} \mathrm{C}$ NMR $(75 \mathrm{MHz}) \delta_{(\mathrm{ppm})}: 156.2(\mathrm{C}-5), 141.6(\mathrm{C}-1), 132.1$ (C-9), 127.4 (C-7), 123.3 (C-10), 120.5 (C-8), 119.7 (CN), 112.7 (C6), 109.8(C-2), 55.6(OMe),24.2 (C-3), 19.1 (C-4). Anal. Calcd. for $\mathrm{C}_{12} \mathrm{H}_{11} \mathrm{NO}$ : C, 77.83; H, 5.94. Found: C, 78.02; H, 6.06.

\section{5-Methoxy-3,4- dihydro-2-naphthoic acid (4)}

A mixture of the nitrile $2(201 \mathrm{mg}, 1.08 \mathrm{mmol})$ and an aqueous solution of potassium hydroxide $(15 \mathrm{~mL}, 50 \%)$ was heated under reflux in a microwave oven at $60 \mathrm{~W}$ for 2 hours at $120^{\circ} \mathrm{C}$. The reaction mixture was cooled, diluted with water, neutralized with aqueous $\mathrm{HCl}$ $(10 \%)$ and extracted with ether $(2 \times 10 \mathrm{~mL})$. The organic extracts were washed, dried and evaporated. The resulting solid on crystallization afforded the acid $4(212 \mathrm{mg}, 96 \%)$, m.p $172-174^{\circ} \mathrm{C}$ (from ether) (lit. ${ }^{10}$ m.p. $\left.177-179^{\circ} \mathrm{C}\right), \mathrm{R}_{\mathrm{f}}$ 0.31(ether), $v_{\max }\left(\mathrm{cm}^{-1}\right): 1725(\mathrm{CO}) ; \mathrm{MS}(\mathrm{m} / \mathrm{e})$ $204\left(\mathrm{M}^{+}\right), 159\left(\mathrm{M}^{+}-\mathrm{COOH}\right)$ and $144\left(\mathrm{M}^{+}-\mathrm{COOH}-\mathrm{Me}\right) ;{ }^{1} \mathrm{H}$ NMR (300MHz) $\delta$ : 7.61 (s, 1H, H-1), 7.14-7.21 (m, 1H, H-7), 6.88-6.83 (d, 2H, J=8.1 Hz, H-6, H-8), 3.83 (s, 2H, OMe), 2.91-2.85 (t, 2H, $\mathrm{J}=8.7 \mathrm{~Hz}), 2.61-2.55$ (t, 2H, J=8.8Hz) $(\mathrm{C}-3, \mathrm{C}-4) ;{ }^{13} \mathrm{C} \mathrm{NMR}(75 \mathrm{MHz})$ : 175.25 (CO), 156.27 (C-5), 138.71 (C-1), 133.28 ( C-9), 128.43 (C-2), 127.08 (C-7), 125.09 (C-10), 112.42 (C-6), 55.68 (OMe), 21.31 (C-3), 19.90 (C-4). Anal. Calcd for $\mathrm{C}_{12} \mathrm{H}_{12} \mathrm{O}_{3}$ : C, 70.58; H, 5.92. Found: C, 70.74; H, 6.04.

\section{5-Methoxy-I , 2, 3, 4-tetrahydro-2-naphthoic acid (5)}

The acid $4(208 \mathrm{mg}$, ) in absolute ethanol $(20 \mathrm{~mL})$ was hydrogenated in presence of Pd-C $(2 \mathrm{mg}, 10 \%)$ at room temperature for 24 hours at atmospheric pressure. Removal of the catalyst by filtration and evaporation yielded the acid $5(221 \mathrm{mg}, 99 \%)$, white crystals, $\mathrm{R}_{\mathrm{f}} 0.91$ (ether), m.p. $148-150^{\circ} \mathrm{C}$ (from $\mathrm{CHCl}_{3}$ ). (lit. $\left.{ }^{1} 147-149^{\circ} \mathrm{C}\right) \cdot v_{\max }\left(\mathrm{cm}^{-1}\right)$ : 3548 (OH), 1710 (CO); MS (m/z): $206\left(\mathrm{M}^{+}\right), 160\left(\mathrm{M}^{+1}-\mathrm{COOH}\right) ;{ }^{1} \mathrm{H}$ NMR $(300 \mathrm{MHz}) \delta_{(\mathrm{pmm})}: 7.11-7.107(\mathrm{t}, 1 \mathrm{H}, \mathrm{J}=7.8 \mathrm{~Hz}, \mathrm{ArH}-7), 6.72-$ $6.71(\mathrm{~d}, 1 \mathrm{H}, \mathrm{J}=7.7 \mathrm{~Hz}, \operatorname{ArH}-8), 6.66-6.65(\mathrm{~d}, 1 \mathrm{H}, \mathrm{J}=8.1 \mathrm{~Hz}, \operatorname{ArH}-6)$, 3.79 (s, 3H, OMe), 3.01-2.89 (m, 3H), 2.76-2.71 (m, 1H), 2.61-2.54 (ddd, $\mathrm{J}=17.4 \mathrm{~Hz}, \mathrm{~J}=10.9 \mathrm{~Hz}, \mathrm{~J}=6.2 \mathrm{~Hz}, 1 \mathrm{H}, \mathrm{H}-2), 2.28-2.25(\mathrm{~m}, 1 \mathrm{H})$,
1.85-1.77 (m, 1H); ${ }^{13} \mathrm{C}$ NMR $(75 \mathrm{MHz}) \delta_{(\mathrm{ppm})}: 182.5(\mathrm{CO}), 157.3(\mathrm{C}-5)$, 136.2 (C-9), 126.5 (C-7), 124.8 (C-10), 121.4 (C-8), 107.5 (C-6), 55.4 (OMe), 39.7 (C-2), 31.7 (C-1), 25.6 (C-3), 22.6 (C-4). Anal. Calcd for $\mathrm{C}_{12} \mathrm{H}_{14} \mathrm{O}_{3}: \mathrm{C}, 69.88 ; \mathrm{H}, 6.84$. Found: C, 70.07; H, 6.96.

\section{Conclusion}

In conclusion, a very convenient approach for the synthesis of the acid 5 has been developed. To the best of our knowledge this is the first report of the acid 5 with a high overall yield. The starting material is commercially available. The present method can be utilized in the synthesis of acid 5 in gram quantities.

\section{Acknowledgements}

Financial support from our institute is gratefully acknowledged.

\section{Conflict of interest}

The author declares no conflict of interest.

\section{References}

1. Oztaskin N, Goksu S, Secen H. An Alternative and Straightforward Synthesis of Dopaminergic 5-Methoxy-1,2,3,4-tetrahydronaphthalen-2-amine. Synthetic Commun. 2011;4(13):2017-2024.

2. Johnson DW, Mander LN. Studies on intramolecular alkylation. VI. ortho-Alkylation in phenolic diazoketones:the preparation of intermediates containing the Cyclohexa-2,4-dienonemoiety suitable for gibberellin synthesis. Aust J Chem. 1974;27(6):1277-1286.

3. McDermed JD, Mckenzie GM, Philips AP. Synthesis and pharmacology of 2-aminotetralins: Dopamine receptor agonists. J Med Chem. 1975;18(4):362-367.

4. Cannon JG, Lee T, Goldman HD. Ceretral dopamine agonist properties of some 2-aminotetralin derivatives after peripheral and intracerebral administration. J Med Chem. 1977;20(9):1111-1116.

5. Cannon JG. Dopamine agonist: Structure-activity relationships. Prog Drug Res. 1985;29:303-414.

6. DeMarinis RM, Shah DH, Hall RF, et al. alpha-Adrenergic agents. 2. Synthesis and alpha 1 -agonist activity of 2 -aminotetralins. J Med Chem. 1982;25(2):136-141.

7. Yao B, Ji HT, Cao Y, et al. Synthesis and antifungal activities of novel 2-aminotetralin derivatives. J Med Chem. 2007;50(22):5293-5300.

8. Oda M, Yamamuro A, Watabe T. One-Pot transformation of ketones to $\alpha, \beta$-unsaturated nitriles via trimethylsiloxy nitriles. Chem Lett. 1979;8(12):1427-1430.

9. Berg S, Larsson LG, Rényi L, et al. (R)-(+)-2-[[[3-(Morpholinomethyl)-2H-chromen-8-yl]oxy]methyl]morpholine Methanesulfonate: A New Selective Rat 5-Hydroxytryptamine1B Receptor Antagonist. $J$ Med Chem. 1998;41(11):1934-1942.

10. Cook Ch, Cho YS, Jew SS, et al. Asymmetric Synthesis of 11-Deoxyanthracycline. Seoul Univ J Pharm Sci. 1983;8:1-10. 